\title{
MARKET RESEARCH, ELABORATION AND CHARACTERIZATION OF PINEAPPLE LIQUEUR
}

\author{
V. Z. Pinto ${ }^{1}$, V. N. Rodrigues ${ }^{1}$, D. F. dos $\operatorname{Santos}^{1}$, G. H. F. dos $\operatorname{Santos}^{1}$, T. B. Bitencourt ${ }^{1}$
}

1 Universidade Federal da Fronteira Sul, Campus Laranjeiras do Sul. Laranjeiras do Sul - PR- Brasil.

$$
\text { *vania.pinto@uffs.edu.br }
$$

\section{RESUMO}

Brazil is the third largest producer of fruits in the world, producing a great variety of fruits throughout the year. Tropical fruits have good distribution and acceptance in the population, as sources of vitamins, minerals and compounds bioactive that aid in the prevention of oxidative stress diseases, such as cancer and cardiovascular diseases. The culture of small centers and rural areas, as well as the regional flora and availability of native trees and fruit, homemade liqueurs are increasing competitiveness with industrialized products. However, some strategies such as marketing research are necessary to help for new product development or even modifications to existing products, since it describes habits and preferences of consumers improving this local product. The objective was to know the habits related to the consumption of alcoholic beverages and to evaluate the consumer's interest about fruit liqueurs, as well as to develop and standardize and characterize a pineapple liqueur, besides assessing the sensorial characteristics of the same. The most of the interviewees do not have the habit of consuming fruit liqueurs, with beer being the preferred alcoholic beverage. Interest in trying a fruit liqueur was almost unanimous among respondents demonstrating the existence of a niche market for fruit liqueur. Alcohol contend was around $18-20^{\circ} \mathrm{GL}$. Reducing sugar and total phenolic compounds are desirable components for flavor and identity of the product and were low after maceration. Consumers testing had no significant difference between all attributes, but it was being observed well-acceptance for all formulations with scores ranging from 6.80 to 7.20 and different concentrations of pineapple do not interfere with the sensorial characteristics of the product. Thus, it was concluded that the production of pineapple liqueurs with lower levels of fruit $(30 \%)$ are accepted and contribute to the economy of production.

KEYWORDS: Ananas comosus, Alcohol beverage, Consumers testing. 


\section{INTRODUCTION}

Due to its tropical characteristic, great territorial extension, and the most diverse climatic conditions, Brazil is the third largest producer of fruit in the world, producing a large amount of fruit throughout the year (Brazilian Fruit, 2012). Fruits are growing as an alternative for the development and recovery of local economies (Bando, Silva, 2001), since it is possible to exploit natural resources sustainably, in addition to the processing of this raw material to obtain products such as pulps, jellies, juices, liqueurs, wines, among others. Fruits and vegetables are sources of vitamins, minerals and bioactive compounds that help prevent diseases associated with oxidative stress, such as cancer and cardiovascular diseases (Guizilini, 2010), these compounds of interest are often preserved during processing or until even extracted, as in the production of liqueurs. With this, products derived from fruits and vegetables can also present these characteristics. Processing makes it a highly perishable raw material in a product with extensive shelf-life (Teixeira et al., 2005).

The pineapple originates from the American continent. However, it is cultivated in Asia and Africa, its fruit belonging to the Bromeliaceae family of the genus Ananas mill has a cylindrical or conical shape, and its pulp has a white, yellow or orange coloration. It has a high concentration of sugars, besides being very nutritious due to the presence of minerals, such as, calcium, phosphorus, magnesium, potassium, sodium, copper and iodine, besides vitamins $\mathrm{C}, \mathrm{A}, \mathrm{B} 1, \mathrm{~B} 2$ and niacin, as well as bromelain source, the enzyme that helps digestion (Granada et al., 2004).

In Brazil, liqueur is a beverage with alcohol content from 15 up to $54 \%$ by volume, at $20^{\circ}$ $\mathrm{C}$, with sugar concentration higher than $30 \mathrm{~g} \mathrm{~L}-1$. It can be made with drinking alcohol or alcoholic distillate, both from agricultural source, alcoholic beverage or mixture of these products. The

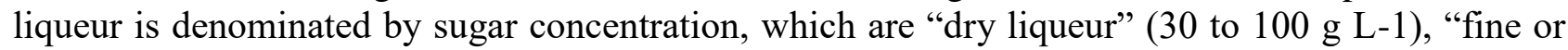
sweet liqueur" (100 to 350 g L-1), "cream" (more than 350 g L-1), "frost or crystallized" (sugar in the proportion of saturation) (Brazil, 2009). Because it is considered a digestive alcoholic beverage, the liqueur is quite consumed after meals, such as dinner (Sebrae, 2012). The culture of small centers and rural areas, as well as the regional flora and availability of native trees and fruit, influence the consumption of homemade liqueurs, increase competitiveness with industrialized products

According to data from the Brazilian Institute of Geography and Statistics (IBGE), between 2008 and 2009 the household food intake of alcoholic beverages was $6.8 \mathrm{~kg}$ per capita/year, been "água ardente," wines and beers the most consumed categories in the country. In addition, the category "other beverages," such as liqueurs and other distillates, in the same consumption period was $0.24 \mathrm{~kg}$ per capita/year (IBGE, 2016). According to Brazilian Association of Beverages (ABRABE), annual sales of liqueur represent approximately 7 million liters. This market is considered as stable, composed from domestic productions by informal way up to significant national and global brands (ABRABE, 2016).

Marketing research is a tool that helps to search some information from the objective analysis for new product development or even modifications to existing products. This device has great importance in the management of marketing strategies, helping at decision-making since it describes habits and preferences of consumers (TEIXEIRA, 1997).

In this context, the elaboration of liqueur becomes a good alternative for the use of seasonal fruits, adding value to the regional production and increasing family and small farmers income. Liqueur processing is simple, requiring little technology. However, the homemade products have no pattern in the production process, resulting in flavors and alcohol concentrations variability, thus, small repeatability in the formulations. The objective was to know the habits related to the 
consumption of alcoholic beverages and to evaluate the consumer's interest about fruit liqueurs, as well as to develop and standardize and characterize a pineapple liqueur, besides assessing the sensorial characteristics of the same.

\section{MATERIAL AND METHODS}

\subsection{Material}

Market research was developed through data collected by a form application in a public square at Laranjerias do Sul, PR city, with volunteers over 18 years and consumers of alcoholic beverages. The experimental elaboration of the liqueurs was performed at the Federal University of Fronteira Sul (UFFS); campus Laranjeiras do Sul, PR. Pineapple liqueur was developed with fresh pineapple, cereal alcohol, refined sugar and mineral water, and all raw materials were buy from Laranjeiras do Sul, PR, Brazil.

\subsection{Market research}

Data collected was using the form to target public description, defined as individuals older than 18 years and it was divided into three parts. In the first part, the questions were related to personal information, such as (a) gender; (b) age; and (c) occupation.

In the second part, the questions, focused on the consumption of alcoholic beverages in general, were: (a) Do you have a habit of buying alcoholic beverages? (b) How often do you drink alcohol? (c) Where do you usually drink alcohol? (d) What type of alcoholic beverages do you most consume? (e) What leads you to try other types of drinks? For questions (c), (d) and (e), it was possible to select more than one answer option. Since, the answers to these questions were for (a) and (b) frequently (every week), sometimes (every month), very little (every 6 months), only on special occasions and I do not buy; (c) at parties, at home, in bars or other; (d) beer, wine, distilled, liqueur and others; (e) curiosity for taste, indication of friends, price, and I always drink the same thing, respectively.

In the third part, the questions were related to the habits and preferences of the fruit liqueurs consume (a) Do you drink fruit liqueur? (b) Are you interested in tasting a tropical fruit liqueur? (c) If you have never tasted any liqueur, why did not taste it? (d) Do you have the habit of buying fruit liqueur? (e) Which liqueur fruit would you be interested in tasting? (f) How much would you be willing to pay per $1 \mathrm{~L}$ of this liqueur? (g) Have you ever produced or know anyone who produces fruit liqueur? (h) If you selected "yes" in the previous question, what is the intended of this production? The answer choices for these questions were (a) frequently (every week), sometimes (every month), very little (every 6 months), almost never and I do not drink, (b) yes or no, (c) lack of opportunity, lack of interest, price or other; (d) frequently (every week), sometimes (every month), very little (every 6 months), only on special occasions and I do not buy; (e) pineapple, strawberry, passion fruit, guabiroba; (f) I would pay more than I paid for similar products, less than I paid for similar products, the value that I pay for similar products, I would buy independent of price and I would not buy it; (g) yes or no, (h) for sale or for own consumption, respectively.

\subsection{Liqueurs elaboration}

After the pineapple was obtained, the fruits were washed in running water, sanitized with sodium hypochlorite $(100 \mathrm{ppm})$ for 20 minutes and washed again with tap water, then the pineapple was manually debarking and cutting (Penha, 2006). The pineapple was submitted to the maceration 
step with cereal alcohol in different fruit concentrations ( $\mathrm{F} 1=30 \%, \mathrm{~F} 2=50 \%$ and $\mathrm{F} 3=70 \%(\mathrm{w}: \mathrm{v})$ ) for 15 days. Maceration is a unitary operation which consists of extracting compounds such as flavor and pigments from the body by a solvent, and it must remain in contact with the solvent for a period (Oliveira et al., 2014). In the case of liqueur production, the alcohol was the solvent, and the pineapple fruit was a the body and source of natural antioxidants, such as phenolic compounds. During maceration, fruit and alcohol were stored in glass bottles and wrapped with aluminum foil to avoid light exposition.

After 15 days of maceration, the fruit and the liquid were separated through simple filtration, and for yield improvement, the fruit was previously blender and filtered on filter paper. Finally, the volume of sugar syrup $(1: 1 \mathrm{w} / \mathrm{v})$ corresponding to $300 \mathrm{~g} \mathrm{~L}^{-1}$ sugar, was added. To know the quantity of syrup required to add to the macerated liquid, to obtain a liqueur with an alcoholic strength around $18{ }^{\circ} \mathrm{GL}$, the Equations (1) and Equation (2) were used; where F is the correction factor, equal to 0.9 , which was determined in preliminary tests. The alcohol content of the macerated liquid was $61.5 \pm 0.95{ }^{\circ} \mathrm{GL}, 54.6 \pm 0.40{ }^{\circ} \mathrm{GL}$ and $50.9 \pm 0.50{ }^{\circ} \mathrm{GL}$, for F1, F2, and F3, respectively.

$$
\begin{aligned}
& \mathrm{C} 1 * \mathrm{~V} 1=\mathrm{C} 2 * \mathrm{~V} 2 * \mathrm{~F} \\
& \mathrm{~V}_{\text {water }}=\mathrm{V} 2-\mathrm{V} 1
\end{aligned}
$$

Equation (2)

Finally, the difference between the water and sugar syrup amount was calculated. Table 1 shows the volumes of syrup and water added to each formulation to obtain products with $18{ }^{\circ} \mathrm{GL}$ and $300 \mathrm{mg} \mathrm{L}^{-1}$ sugar.

Table 1- Syrup and water volume (mL) added to diluted which liqueur formulation

\begin{tabular}{ccc}
\hline Formulation & Syrup Volume $(\mathbf{m L})$ & Water Volume $(\mathbf{m L})$ \\
\hline 1 & 1286.95 & 292.96 \\
2 & 1243.67 & 214.11 \\
3 & 1583.55 & 215.71 \\
\hline
\end{tabular}

\subsection{Physical-Chemical Characterization}

The macerated liquid, as well as, ready liqueurs were analyzed by distillation method for alcohol quantification followed by density determination by pycnometer as described by the Instituto Adolfo Lutz (2008), in triplicate. Reducing sugar concentration was performed by the methodology described by Wang (2016) using $1 \%$ dinitrosalicylic acid (DNS) reaction. A standard curve was constructed with glucose at concentrations $0.781 ; 1.563 ; 3.125 ; 6,250 ; 12,500 ; 25,000$

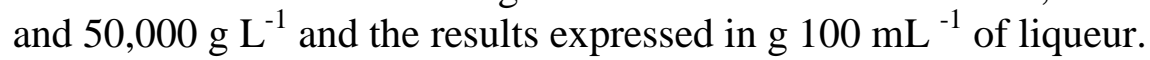

The total phenolic compounds of the pineapple liqueurs were quantified according to the method described by Lopez and Juan (2012) through the reaction with Folin-Ciocalteau (0,25N) and spectrophotometer reading at $760 \mathrm{~nm}$. A standard curve with gallic acid $(\mathrm{GA})$, at concentrations $0 ; 0.043 ; 0.087 ; 0.130 ; 0.173 \mathrm{mM}$ was used to determine the total phenol concentration, and the results expressed as mg GA $100 \mathrm{~mL}^{-1}$ of lequeur. 


\subsection{Consumers testing}

A total of 60 consumers over 18 years of age participated in the consumer testing of pineapple liqueurs. Ethics approval was obtained from Research Ethics Committee (CEP) from UFFS, number CAAE: 55891816.1.0000.5564 and Free and Informed Consent Term (TCLE) were read and sing for every participant. Consumers were verbally screened for the tendency to alcoholism and advertised to did not drive for 40 minutes after the testing. During testing, consumers were asked to rate their liking of the color flavor and their overall liking of the products on a 9-point hedonic scale (1-disliked very much; 9- liked very much). Also, the purchase intent was evaluated on a 5-point hedonic scale (certainly would buy (5) would certainly not buy), as well as a space for comments and suggestions.

\subsection{Statistical analysis}

The results of the characterization of the liqueurs were submitted to analysis of variance and Tukey test at $5 \%$ of significance.

\section{RESULTS AND DISCUSSION}

\subsection{Consumers profile}

The market research was performed with 100 people which were between 18 and 65 years old, and $51 \%$ of the participants were male. When analyzing the occupation of the participants, it was verified that $50 \%$ only study, $32 \%$ only work, $17 \%$ study and work and only $1 \%$ do not study and do not work. With this, it was possible to verify diversified public and potential consumers of alcoholic beverages.

When participants were questioned about the frequency of alcohol beverages consumption, $45 \%$ reported drinking alcoholic beverages every month, while $37 \%$ said they did it weekly. In addition, it was observed that the parties are the places with the highest consumption of alcohol beverages $(69 \%)$ and $56 \%$ responded to consume it at home, $31 \%$ in bars and $4 \%$ others, being the house of friends the most cited.

Regarding the habit of buying alcoholic beverages, most (39\%) said buy every month, and $36 \%$ said they buy every week, and beers are described as the most consumed alcoholic drink $(85 \%)$, followed by distillates $(27 \%)$, while liqueur presented only $10 \%$. It was also verified that the price of the product is not a relevant factor for the consumer to try new drinks, and $78 \%$ of the participants affirm that the curiosity about the taste of the product is the factor that leads them to try a new drink and $23 \%$ by friends indication.

In addition, the fruit liqueurs consumption is low (Figure 1), since only $12 \%$ of the participants consume every month, and only $2 \%$ drink it every week, just $7 \%$ said they had never tried the product because of lack of interest. However, $98 \%$ of the participants showed interest in proving this product. 


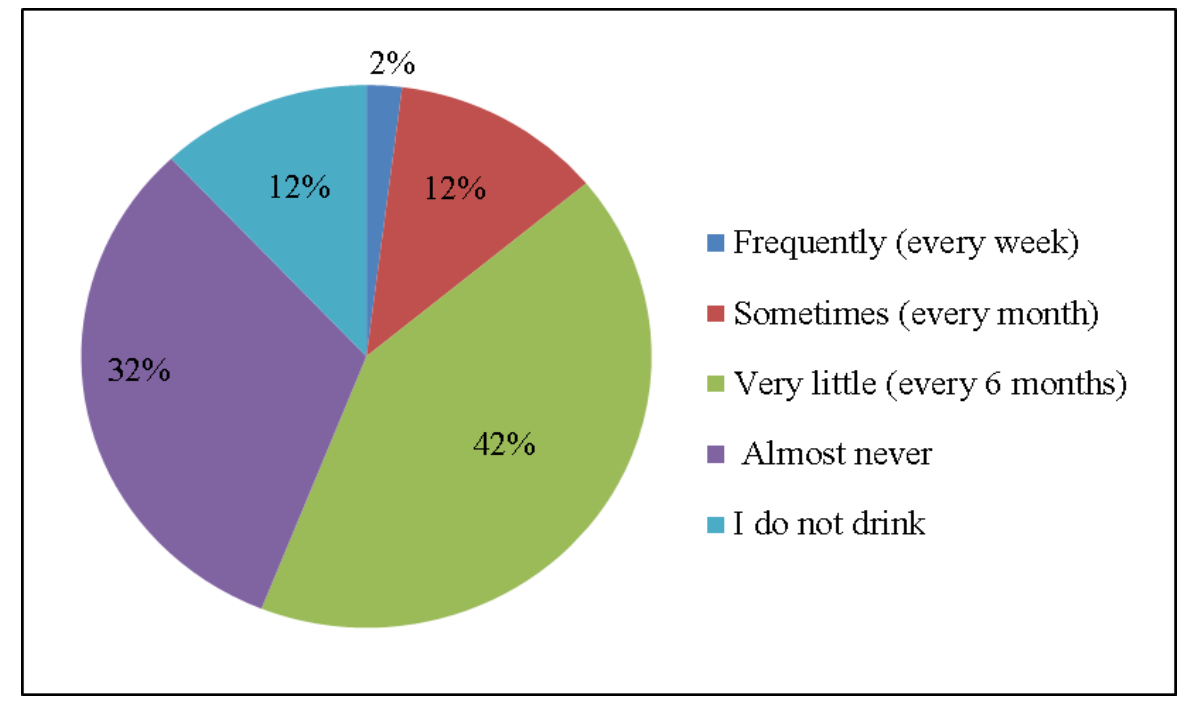

Figure 1- Fruit liqueur consumption.

Concerning about the size of fruit liqueur packaging, most participants were more interested in packaging with lower volume, with $37 \%$ of participants stating that they would be interested in purchasing a $250 \mathrm{~mL}$ package and $34 \%$ would buy one $500 \mathrm{~mL}$ bottle.

When questioned about the price that would be paid for the product, 59\% of participants would be willing to pay the same price for similar products, and $20 \%$ would buy regardless of cost, while only $1 \%$ would not buy regardless of cost. Participants were also asked if they knew anyone who produced fruit liqueur, with just $37 \%$ of the participants knowing it and just $20 \%$ of them are fruit liqueur producer for sale. Among the fruits suggested, 30\% reported being interested in a passion fruit liqueur, 26\% pineapple, $23 \%$ guabiroba and $16 \%$ strawberry, and some participants suggested fruits such as jabuticaba and orange.

\subsection{Physical-Chemical Characterization}

After addition of the syrup and water volume required in each formulation, the alcohol content analysis was performed (Table 1). The obtained values diverge from the expected value that was $18{ }^{\circ} \mathrm{GL}$. However, there is no statistical difference between the alcoholic content of the three formulations. Therefore, other tests must be done to find a correction factor that best adjusts to the behavior of this dilution. According to Teixeira (2005) liqueurs with alcohol content between 18 to $25^{\circ} \mathrm{GL}$ are the most accepted by consumers.

The concentration of reducing sugars $\left(\mathrm{g} 100 \mathrm{~mL}^{-1}\right)$ did not change between the formulations (Table 2). The amount of these sugars is results of natural sugars formed during fruit ripening (Rodolfo, 2000), as well as, some add sugar in liqueur preparation. However, only commercial sugar, which is majority compound by sucrose, was used in the liqueur samples.

The total phenolic compounds increased by fruit concentration increase for alcoholic maceration (Table 2). Sample 1 had only $30 \%$ of fruit (w:v) during this steep, which results in the lower amount of total phenolic compounds $(\mathrm{p}<0.05)$. The amount of this compounds also are result of ripening process (Rodolfo, 2000), maceration solvent, amount of fruit (Nascimento et al. 2010), as well as, fruit growing temperature, localization, soil fertility and others. Sugars and phenolic compounds are two desirable components for flavor and identity of the product. So, the raw 
material is the most important factor for quality of flavors, tasty and bioactive extraction for liqueur production.

Table 2- Alcohol content, reducing sugar content, total phenolic compounds content in pineapple liqueurs.

\begin{tabular}{|c|c|c|c|}
\hline Formulation* & Alcohol concent $\left({ }^{\circ} \mathbf{G L}\right)$ & $\begin{array}{l}\text { Reducing Sugar } \\
\quad\left(\text { g } 100 \mathrm{~mL}^{-1}\right)\end{array}$ & $\begin{array}{c}\text { Total phenolic } \\
\text { compounds (mg AG } 100 \\
\left.\text { mL }^{-1}\right)\end{array}$ \\
\hline 1 & $19.23 \pm 0.41^{\mathrm{a}}$ & $0.70 \pm 0.03^{a}$ & $0.29 \pm 0.02^{b}$ \\
\hline 2 & $18.93 \pm 0.45^{\mathrm{a}}$ & $0.75 \pm 0.06^{\mathrm{a}}$ & $0.37 \pm 0.01^{\mathrm{a}}$ \\
\hline 3 & $19.57 \pm 0.66^{\mathrm{a}}$ & $0.77 \pm 0.03^{\mathrm{a}}$ & $0.40 \pm 0.01^{\mathrm{a}}$ \\
\hline
\end{tabular}

* Mean \pm Standard Deviation of Mean. The averages followed by the same letter do not differ statistically from each other by the Tukey test at $5 \%$ significance $(\mathrm{p}<0.05)$.

The results of the consumer liking trial can be seen in Table 3. An intermediate acceptance was observed for color, flavor, taste and overall impression attributes in all formulations, scores ranging from 6.80 to 7.20 , confirming that there is no rejection of the samples. Among all the formulations, for all evaluated attributes, there was no difference in the opinion of the evaluators ( $\mathrm{p}$ <0.05). Purchase intent had a score ranging from 3.45 to 3.70 (maybe bought, maybe not bought), and no difference was verified between the three formulations $(\mathrm{p}<0.05)$ (Table 3$)$.

Table 3- Consumers liking of pineapple liqueur

\begin{tabular}{cccccc}
\hline Formulation* & Color & Taste & Flavor & $\begin{array}{c}\text { Overall } \\
\text { Impression }\end{array}$ & $\begin{array}{c}\text { Purchase } \\
\text { Intent }\end{array}$ \\
\hline $\mathbf{1}$ & $6.80 \pm 0.20^{\mathrm{a}}$ & $7.37 \pm 0.18^{\mathrm{a}}$ & $7,13 \pm 0.16^{\mathrm{a}}$ & $7,27 \pm 0.16^{\mathrm{a}}$ & $3.60 \pm 0.13^{\mathrm{a}}$ \\
$\mathbf{2}$ & $7.08 \pm 0.17^{\mathrm{a}}$ & $7.03 \pm 0.19^{\mathrm{a}}$ & $6,98 \pm 0.18^{\mathrm{a}}$ & $7,10 \pm 0.14^{\mathrm{a}}$ & $3.45 \pm 0.12^{\mathrm{a}}$ \\
$\mathbf{3}$ & $7.20 \pm 0.16^{\mathrm{a}}$ & $7.40 \pm 0.16^{\mathrm{a}}$ & $6,97 \pm 0.16^{\mathrm{a}}$ & $7,37 \pm 0.14^{\mathrm{a}}$ & $3.70 \pm 0.14^{\mathrm{a}}$ \\
\hline
\end{tabular}

* Mean \pm Standard Deviation of Mean. The averages followed by the same letter do not differ statistically from each other by the Tukey test at $5 \%$ significance $(\mathrm{p}<0.05)$.

The results obtained in this study were similar to those found in the pineapple and acerola liqueur by Nascimento et al. (2010) and reported score average of 7.35, 6.98, 7.42, for the attributes color, flavor, and texture, respectively. The same authors reported an average of 4.23 for the purchase intent.

Since the consumers did not observe a significant difference between the formulations, the use of lower concentrations of pineapple, for liqueur production will not interfere in the sensorial attributes of this beverage; however, will contribute to the economy in the production of the same. A similar result was found by Almeida et al. (2012), who, when subjecting liqueurs produced with different amounts of tangerine peel to the sensory evaluation, and described that the treatment with less peel concentration had the lowest score for the flavor attribute.

\section{CONCLUSION}


Market research was targeted at alcohol drinkers who showed a habit of frequent drinking. However, most of the interviewees do not have the habit of consuming fruit liqueurs, with beer being the preferred alcoholic beverage. Interest in trying a fruit liqueur was almost unanimous among respondents demonstrating the existence of a niche market for fruit liqueur.

Alcohol content is in according with Brazilian legislation and the reducing sugar $\left(\mathrm{g} 100 \mathrm{~mL}^{-}\right.$ $\left.{ }^{1}\right)$ and total phenolic compounds (mg AG $\left.100 \mathrm{~mL}^{-1}\right)$ are desirable components for flavor and identity of the product and the raw material is the most important factor for quality of flavors, tasty and bioactive extraction for liqueur production.

The elaboration of pineapple liqueur presents itself as a good alternative for the utilization of the fruits, allowing an increase in the income of small farmers because it requires little technology in the production. In the consumers testing, all three formulations were well-accepted, with scores ranging from 6.80 (I liked slightly) to 7.20 (I liked regularly). The consumers liking characterization also shows that different concentrations of pineapple do not interfere with the sensorial characteristics of the product. Thus, it is concluded that the production of pineapple liqueurs with lower levels of fruit (30\%) are accepted and contribute to the economy of production.

\section{ACKNOWLEDGMENTS} Científica.

The authors thank the Federal University of Fronteira Sul for the scholarship of Iniciação

\section{REFERENCES}

ASSOCIAÇÃO BRASILEIRA DE BEBIDAS. Categorias de mercado. Available in: http://www.abrabe.org.br/categorias/. Acess in: 14 jun. 2016.

Almeida, E. L., Lima, L. C., Borges, V. T. N., Martins, R. N., Batalini, C. Elaboração De Licor De casca de tangerina. Alimentos e Nutrição, v. 23, p.259-265, 2012.

Bando, P. M., Silva, C. A. B. Sistema agroindustrial de frutas na zona da mata mineira: agentes, organizações e ambiente institucional. Revista Ceres, n.48, v. 277, p.311-331, 2001.

BRASIL. Casa Civil. Decreto no 6.871, de 4 de junho 2009. Regulamenta a Lei no 8.918, de 14 de julho de 1994, que dispõe sobre a padronização, a classificação, o registro, a inspeção e a fiscalização da produção e do comércio de bebidas. Diário Oficial da União.

Brazilian Fruit (2012). Disponível em http://www.brazilianfruit.org.br/newbrazilianfruit.asp. Acess in: 14 jun. 2016.

Dutcosky, S. D. (2013). Análise Sensorial de Alimentos (4. ed). Curitiba: Champagnat.

Granada, G. G., Zambiazi, R. C., Mendonça, C. R. B. Abacaxi: produção, mercado e subprodutos. Boletim Centro de Pesquisa de Processamento de Alimentos, n. 22, v. 2, p.405-422, 2004.

Guizilini, L.A. Atividade antioxidante de gabiroba e aplicação da polpa como ingrediente em sorvete. (Dissertação de Mestrado). Universidade Estadual de Londrina, Londrina, 2010

Instituto Adolf Lutz. Normas analíticas, métodos químicos e físicos para análise de alimentos. (3. ed.) São Paulo: Instituto Adolf Lutz, 2008. 1020p

INSTITUTO BRASILEIRO DE GEOGRAFIA ESTATÍSTICA. Available in: http://www.ibge.gov.br/home/estatistica/populacao/condicaodevida/pof/2008_2009_aquisicao/default140_zip.shtm. Acess in: 15 abr. 2016.

LÓPEZ, P. J.; JUAN, T. G. Determinación del contenido total de polifenoles en alimentos con el reactivo de folinciocalteau. Nutrición y Bromatología. Universidad de Valladolid 2012. 
Nascimento, N. T., Frutuoso, A. E., Moraes, K. F., Soares, D. L., Silva, E. D. L., Farias, M. D. Elaboração de um licor funcional a base de Acerola (Malpighia emarginata) com Abacaxi (Ananas comosus). Connepi, Sobrak, p.1-6, jan., 2010

Oliveira, E. N. A., Santos, D. C., Santos, Y. M. G., Oliveira, F. A. A. Aproveitamento agroindustrial da graviola (Annona muricata L.) para produção de licores: Avaliação sensorial. Journal of Biotechnology and Biodiversity, v.5, p.33-42, feb. 2014.

Penha, E. M. Licor de frutas. Brasília: Embrapa Agroindústria de Alimentos, 2006, 36p.

Pereira, M. C. (2011). Avaliação de compostos bioativos em frutos nativos do Rio Grande do Sul. (Dissertação de Mestrado). Universidade Federal do Rio Grande do Sul, Porto Alegre,

Rodolfo, D. H.; Reinhardt, C. Colheita e beneficiamento. In: Gonçalves, N. B. (Org.). Abacaxi: pós-colheita. Brasília, DF: Embrapa Comunicação para Transferência de Tecnologia; Rio de Janeiro: Embrapa Agroindústria de Alimentos, 200045 p. il. (Frutas do Brasil, 5).

Sebrae. Cachaça artesanal, série estudos mercadológicos, 2012.

Sucupira, N.R., Xerez, A.C.P., Souza. P.H.M. Perdas vitamínicas durante o tratamento térmico de alimentos. Científica Ciência Biológica e da Saúde. n.2, v 14, p.121-128, 2012.

Teixeira, L. J. Q., Ramos, A. M., Chaves, J. B. P., Silva, P. H. A., Stringheta, P. C. Avaliação tecnológica da extração alcoólica no processamento de licor de banana. Boletim Centro de Pesquisa de Processamento de Alimentos. n.2, v.23, p.329-346, 2005.

WANG, Nam Sun. Experiment no. 4a: glucose assay by dinitrosalicylic colorimetric method. Department of Chemical \& Biomolecular Engineering University of Maryland. Available in: http://www.eng.umd.edu/ nsw/ench485/lab4a.htm. Acess in: 26 out. 2016. 